\title{
Physiological performance by growth rate, pigment and protein content of the brown seaweed Sargassum filipendula (Ochrophyta: Fucales) induced by moderate UV radiation exposure in the laboratory
}

\author{
Luz K. Polo, Fungyi Chow \\ Laboratory of Marine Algae "Édison José de Paula", Department of Botany, Institute of Biosciences, \\ University of São Paulo, CEP 05508-090, São Paulo, Brazil. \\ (LP) (Corresponding author) E-mail: luzkapolo@gmail.com. ORCID iD: https://orcid.org/0000-0002-9318-4042 \\ (FC) E-mail: fchow @ib.usp.br. ORCID iD: https://orcid.org/0000-0003-2462-3117
}

\begin{abstract}
Summary: UV radiation is a factor affecting the distribution and physiology of photosynthetic organisms in an aquatic ecosystem. Studies with macroalgae indicate diverse biological disturbances in response to UV radiation. This work aimed to study sensitivity of the brown macroalga Sargassum filipendula exposed to UV radiation: PAR (control), PAR+UVA+UVB(++) and PAR+UVA(++)+UVB. Changes in the physiological parameters growth rate, total soluble proteins, photosynthetic pigments and the UV-vis absorbing compounds were analysed after T0, T4, T7 and T10 (days) of UV exposure. Physiological parameters showed little variation between treatments and over time, suggesting that moderate UV radiation doses could regulate resistance responses to re-establish the cellular homoeostasis condition through activation of an antioxidant defence system, such as an overproduction of phenolic compounds. Responses recorded in S. filipendula would be related to acclimation mechanisms against acute UV radiation stress, triggering resistance responses to avoid serious damage to the metabolic machinery, activating control systems to maintain hormesis, and homoeostasis of deleterious actions of reactive species, similar to the phenomenon known as preparation for oxidative stress. Finally, UV-visible absorption spectra showed absorption bands evidencing the presence of mainly UV-absorbing compounds with photoprotective function, such as phlorotannins, flavonoids and carotenoids, which could provide adaptive advantages for organisms exposed to UV radiation.
\end{abstract}

Keywords: algae; growth rate; photosynthetic pigments; proteins; ultraviolet radiation; UV-absorbing compounds.

Rendimiento fisiológico de acuerdo a la tasa de crecimiento, contenido de pigmentos y proteínas de la macroalga parda Sargassum filipendula (Ochrophyta: Fucales) inducida a radiación UV en el laboratorio

Resumen: La radiación UV es un factor que afecta la distribución y la fisiología de los organismos fotosintéticos en el ecosistema acuático. Los estudios con macroalgas indican diversas alteraciones biológicas en respuesta a la radiación UV. Este trabajo tuvo como objetivo estudiar la sensibilidad de la macroalga parda Sargassum filipendula expuesta a radiación UV: PAR (control), PAR + UVA + UVB (++) y PAR + UVA (++) + UVB. Los cambios en la tasa de crecimiento, proteínas solubles totales, pigmentos fotosintéticos y compuestos absorbentes de UV-vis se analizaron después de T0, T4, T7 y T10 (días) de exposición a UV. Los parámetros fisiológicos mostraron poca variación entre los tratamientos y con el tiempo, lo que sugiere que dosis moderadas de radiación UV podrían regular las respuestas de resistencia para restablecer la condición de homeostasis celular a través de la activación del sistema de defensa antioxidante, como la sobreproducción de compuestos fenólicos. Las respuestas registradas en S. filipendula estarían relacionadas con mecanismos de aclimatación contra el estrés agudo por radiación UV, desencadenando respuestas de resistencia para evitar daños severos en la maquinaria metabólica, activando sistemas de control para mantener la hormesis y homeostasis de acciones deletéreas de especies reactivas, similar al fenómeno llamado preparación para el estrés oxidativo (POS). Finalmente, los espectros de absorción UV-visible mostraron bandas de absorción que evidencian la presencia de compuestos absorbentes de UV principalmente con función fotoprotectora, como los florotaninos, flavonoides y carotenoides que podrían proporcionar ventajas adaptativas para los organismos expuestos a la radiación UV.

Palabras clave: algas; tasa de crecimiento; pigmentos fotosintéticos, proteínas, radiación ultravioleta; compuestos absorbentes de rayos UV.

Citation/Como citar este artículo: Polo L.K., Chow F. 2020. Physiological performance by growth rate, pigment and protein content of the brown seaweed Sargassum filipendula (Ochrophyta: Fucales) induced by moderate UV radiation exposure in the laboratory. Sci. Mar. 84(1): 59-70. https://doi.org/10.3989/scimar.04982.22A

Editor: X. Turon.

Received: July 29, 2019. Accepted: December 20, 2019. Published: February 4, 2020.

Copyright: $\odot 2020$ CSIC. This is an open-access article distributed under the terms of the Creative Commons Attribution 4.0 International (CC BY 4.0) License. 


\section{INTRODUCTION}

Solar radiation is the most important prerequisite for life on Earth, since it provides the light, heat and energy demanded for photosynthesis processes. This radiation mainly consists of UV radiation, visible light (photosynthetically active radiation, PAR), and infrared radiation (Diffey 2002). The UV radiation corresponds to a small part of the electromagnetic spectrum and is divided into three spectral regions: 1) UVA (400-315 nm), which is the closest radiation to the visible spectrum and is not absorbed by the ozone $\left(\mathrm{O}_{3}\right)$ layer; 2) UVB (315-280 nm), which is not completely absorbed by $\mathrm{O}_{3}$ and is harmful to living organisms; and 3) UVC (280-100 nm), which is extremely harmful but is quantitatively absorbed by oxygen and ozone in the Earth's atmosphere (Madronich et al. 1998).

Since man-made changes in the stratospheric $\mathrm{O}_{3}$ layer began to be reported, the effect of UV radiation on the aquatic ecosystem has become an important subject. Interactions between global climate change, $\mathrm{O}_{3}$ and UV radiation are having important consequences for UV exposure in this ecosystem (Bais et al. 2015). However, the attenuation of UV radiation that penetrates the water column varies according to the location (e.g. oceanic versus coastal environments), latitude, and concentrations of particulate and dissolved matters (Villafañe et al. 2003). UV radiation has been considered one of the main factors affecting the distribution of photosynthetic organisms in the aquatic ecosystem. It has diverse biological effects, most of them with unfavourable consequences (Björn 2007).

Macroalgae are major biomass producers on rocky shores and the continental shelf, which provide microhabitats for many larval stages of fishes, crustaceans, epibionts and epiphytes, and other marine organisms (Lippert et al. 2001). Due to tidal exposure, intertidal macroalgae are constantly exposed to fluctuating environmental stresses such as high temperature, desiccation and high radiation levels (PAR and UV radiation) (Sampath-Wiley et al. 2008) that could easily lead to the formation and accumulation of free radicals and reactive species, triggering oxidative stress. Photobiological studies in macroalgae indicate diverse physiological disturbances in response to UV radiation, including alterations in growth and development (Altamirano et al. 2003, Gao and Xu 2008, Navarro et al. 2016), pigment degradation (Heo and Jeon 2009), dynamic or chronic photoinhibition of photosynthesis (Barufi et al. 2011, Ayres-Ostrock and Plastino 2014, Figueroa et al. 2014), protein and DNA damage (Buma et al. 2001, Kumar et al. 2004), decrease in lipid/fatty acid content (Khotimchenko and Yakovleva 2005, Liang et al. 2006), inhibition of enzyme activity (Lee and Shiu 2009), alterations in polyamines content (Polo et al. 2014b), and modifications in cellular organization and ultrastructure (Holzinger and Lütz 2006, Polo et al. 2014a, Schmidt et al. 2015). As a photoprotective mechanism against UV radiation, especially UVB, macroalgae can increase the production of UV-absorbing compounds such as mycosporine-like amino acids, phenolic compounds and carotenoids, which play protective roles by mitigating the damage caused by the increase in reactive species (Ruhland et al. 2007), therefore giving advantages that enable macroalgae to survive in the presence of UV radiation.

The genus Sargassum C. Agardh is dominant in the coverage of coastal consolidate substrate areas in both tropical and subtropical regions, often forming the so-called Sargassum beds. It plays an important ecological role as shelter, protection and a food resource for several marine species (Széchy et al. 2001) and is considered a host because it provides microhabitats for several other algae and marine fauna. The genus is highly sensitive to variations in salinity, temperature, and pollutants (Paula and Eston 1987, Gorostiaga and Díez 1996, Amado Filho et al. 1999), an interesting requisite of bioindicator species. In addition, the position that Sargassum occupy in the littoral zone, between the lower intertidal and the infralittoral, means that they are subjected to higher levels of UV radiation with possible consequences on their general performance, which may cause shifts within the whole ecosystem due to their role as community engineers providing a habitat and energy source (Häder et al. 2007).

Given the many changes that UV radiation may have on seaweeds, it is important to study the sensitivity and tolerance of these organisms in order to understand possible biological consequences under an extremely dynamic environment and predicted global climate changes scenarios. Therefore, the aim of this study was to evaluate the biological effect of a moderate dose of UV radiation (UVA and UVB) on the physiological performance and sensitivity of the brown macroalga Sargassum filipendula C. Agardh by analysing growth rate, photosynthetic pigments (chlorophyll (Chl) $a$, Chl $c$, and carotenoids), total soluble proteins and UV-absorbing compounds under laboratorial conditions.

\section{MATERIALS AND METHODS}

\section{Collection site and algal material}

Specimens of S. filipendula were collected at Cigarras Beach $\left(24^{\circ} 43^{\prime} 55.74^{\prime \prime} \mathrm{S}\right.$ and $\left.45^{\circ} 23^{\prime} 54.48^{\prime \prime} \mathrm{W}\right)$ located in São Sebastião on the north coast of São Paulo State, Brazil, during the summer season (February-March 2016). Material was transported in cooler boxes to the laboratory, cleaned of macroepiphytes and washed with abundant filtered seawater. Five individuals were fixed in $4 \% \mathrm{v} / \mathrm{v}$ formaldehyde (diluted in seawater), herborized and then deposited in the SPF Herbarium of the University of São Paulo (voucher SPF 58087). The remaining biomass was used for subsequent experiments.

Cleaned apical portions $( \pm 8 \mathrm{~cm})$ were acclimated for one week under laboratory conditions in sterilized seawater at 32 psu enriched with von Stosch solution diluted to 50\% (Ursi and Plastino 2001) based on Edwards (1970), with a PAR of $60 \pm 5 \mu \mathrm{mol}$ photons $\mathrm{m}^{-2}$ $\mathrm{s}^{-1}, 25 \pm 1^{\circ} \mathrm{C}$, a photoperiod of $14 \mathrm{~h}$ and intermittent aeration every $30 \mathrm{~min}$. The culture ratio was $3 \mathrm{~g}$ of alga per $1 \mathrm{~L}$ of culture medium. 
Table 1. - Values of total radiation doses and intensities for PAR, PAR+UVA+UVB (++) and PAR+UVA (++) +UVB treatments. The total dose was calculated from the absolute intensity values for $1,4,7$ and 10 days (d). UVA and UVB irradiance were $2.01 \mathrm{~W} \mathrm{~m}^{-2}$ and $7.04 \mathrm{~W}$

\begin{tabular}{|c|c|c|c|c|c|c|}
\hline \multirow[t]{2}{*}{ Treatment } & \multicolumn{2}{|c|}{ Total irradiance } & \multicolumn{4}{|c|}{ Total dose $\left(\mathrm{KJ} \mathrm{m}^{-2}\right)$} \\
\hline & Time UV/d (h) & Absolute intensity $\left(\mathrm{W} \mathrm{m}^{-2}\right)$ & $1 \mathrm{~d}$ & $4 d$ & $7 \mathrm{~d}$ & $10 \mathrm{~d}$ \\
\hline PAR & - & 13.04 & 563.32 & 2253.31 & 3943 & 5633.33 \\
\hline PAR+UVA+UVB(++) & 3 & 15.05 & 1950.5 & 7801.9 & 13653.4 & 19505 \\
\hline PAR+UVA(++)+UVB & 3 & 20.08 & 2602.4 & 10409.5 & 18216.6 & 26023.7 \\
\hline
\end{tabular}

\section{Laboratory conditions and experimental setup}

After the acclimation period, the material was exposed to three different radiation treatments: a) PAR (control treatment), b) PAR+UVA+UVB(++) and, c) PAR+UVA(++)+UVB under the laboratory culture conditions described above, using five biological replicates for each treatment. The experiments were performed under $3 \mathrm{~h}$ exposure to UVR per day in the middle of the light phase for ten days. During this exposure, aeration was increased in all treatments to encourage greater movement of the algal fragments in order to promote a homogeneous exposure for all branches, and culture medium was added at the seventh day of exposure to avoid nutrient limitation.

UVB (312 nm; $2.04 \mathrm{~W} \mathrm{~m}^{-2} ; 21.71 \mathrm{~kJ} \mathrm{~m}^{-2}$ day $\left.^{-1}\right)$ and UVA (365 nm; $7.04 \mathrm{~W} \mathrm{~m}^{-2} ; 76.32 \mathrm{~kJ} \mathrm{~m}^{-2}$ day $^{-1}$ ) radiations were provided by Philips lamps models TL 20W/12 and Actinic BL TL-K 40 W/10-R, respectively. Table 1 presents the values of total radiation doses and intensities for the different treatments for 1, 4, 7 and ten days of UV exposure.

The measurements of total radiation spectrum emitted by radiation sources (PAR and UV) were obtained using the SphereOptics SMS-500 (Spectral Measurements System) spectroradiometer and are summarized in Figure 1. It must be taken into account that the Philips TL12 UVB lamp also has emission in the UVA region of the spectra in a ratio of 0.51 (UVB/UVA), and the same occurs for BL TL-k40, which also has emission in the UVB region in a ratio of 0.04 (UVA/UVB).

The UVR intensities were chosen based on previous studies with brown macroalgae (Bischof et al. 1998, Holzinger et al. 2011, Cruces et al. 2013), in which the selected intensities did not cause an acute stress in response to UVR and are therefore considered to have a moderate impact.

The PAR irradiance intensity measurements were obtained in $\mu \mathrm{mol}$ photons $\mathrm{m}^{-2} \mathrm{~s}^{-1}$ using a LI-COR

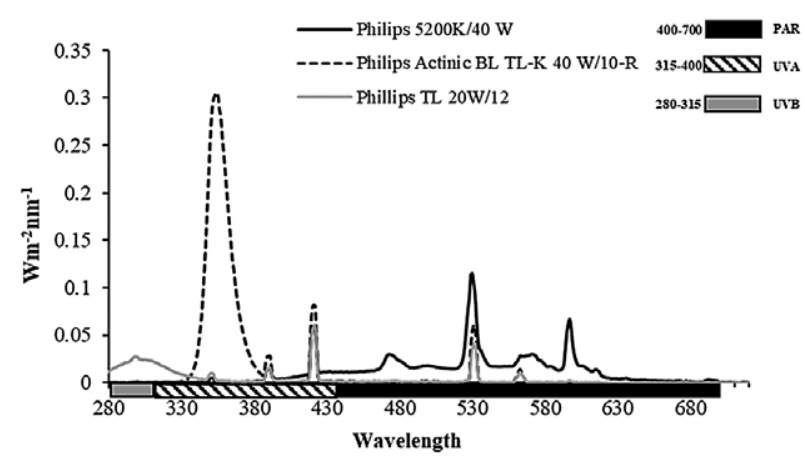

Fig. 1. - Total radiation spectrum emitted by radiation sources: PAR (400-700 nm), UVA (315-400 nm) and UVB (280-315 nm).
Biosciences Model Li-250A quantameter (LincolnNebraska, USA) connected to the underwater spherical LI-COR sensor SPQSA1346 (USA). The UVR intensity was obtained in $\mathrm{W} \mathrm{m} \mathrm{m}^{-2}$, with a MACAM Ultraviolet Radiometer (Scotland) connected to the UVB or UVA specific sensors. The measurements of total radiation spectrum emitted by radiation sources (PAR and UV) were obtained using the SphereOptics SMS-500 (Spectral Measurements System) spectroradiometer (USA).

Growth rate (GR), total soluble proteins, and photosynthetic pigments were evaluated before the start of the experiment (T0) and after 4, 7, and 10 days (T4, T7 and $\mathrm{T} 10$, respectively).

\section{Growth rate}

The growth rate was evaluated through measurements of fresh biomass weight over the experimental period (t), following Penniman et al. (1986) as follows, where Wi is the initial wet mass, Wf is the final wet mass, and $t$ is the time in days:

$$
\mathrm{GR}\left[\% \mathrm{day}^{-1}\right]=\left[(\mathrm{Wf} / \mathrm{Wi})^{1 / \mathrm{t}}-1\right] \times 100
$$

\section{Total soluble proteins and photosynthetic pigments, and UV/visible-absorbing spectrum}

The soluble proteins and photosynthetic pigments were extracted from frozen fresh samples of approximately $70 \mathrm{mg}$ fresh weight (FW) at T0, T4, T7 and $\mathrm{T} 10$. The material was ground in liquid nitrogen until a fine powder was obtained, extracted in $1 \mathrm{~mL}$ of cold sodium phosphate buffer $0.05 \mathrm{mM}$ ( $\mathrm{pH} 5.5)$, protecting the extract from photo- and thermooxidation, and then centrifuged for $15 \mathrm{~min}$ at $4^{\circ} \mathrm{C}$ and $12000 \mathrm{rpm}$. The obtained supernatant was called buffered extract.

From an aliquot of the buffered extract, the total soluble protein content was analysed according to the Bradford spectrophotometric method (Bradford 1976) using the Bio-Rad solution for the protein assay (Bio-Rad, USA), and the absorbance at $595 \mathrm{~nm}$ was recorded in a UV-visible 96-well microplate spectrophotometer. Bovine serum albumin was used for the standard curve with concentrations ranging from 2 to $16 \mu \mathrm{g} \mathrm{mL} \mathrm{L}^{-1}\left(\mathrm{y}=0.0434 \mathrm{x}+0.049 ; \mathrm{R}^{2}=0.97\right)$.

From the pelleted material obtained after the extraction of soluble proteins, photosynthetic pigments were analysed by resuspending the pellet in $1.5 \mathrm{~mL}$ of methanol and extracted for $3 \mathrm{~h}$ at $4^{\circ} \mathrm{C}$, protecting the extract from photo- and thermaloxidation. Subsequently, centrifugation was carried out for $15 \mathrm{~min}$ at $12000 \mathrm{rpm}$ and $4^{\circ} \mathrm{C}$. The obtained supernatant was called methanolic extract. From an aliquot of $300 \mu \mathrm{L}$ of the methanolic extract, UV-absorbing and visible-absorbing com- 
pounds were analysed by determining the absorption spectrum in a UV-visible microplate spectrophotometer by reading the absorbance in the range of 200 to $750 \mathrm{~nm}$. Chl $a$ and Chl $c$ content was calculated using the absorbance coefficients (E $\lambda$ ) from Ritchie (2008) for methanol, where $E \lambda_{632}=16.4351$ and $E \lambda_{665}=3.2416$ for Chl $a$ and $\mathrm{E} \lambda_{632}=34.2247$ and $\mathrm{E} \lambda_{665}=1.5492$ for $\mathrm{Chl}$ $c$, following the formulas:

$$
\text { Chl a }\left(\mu \mathrm{g} \mathrm{g} \mathrm{FW}^{-1}\right)=16.4351 \mathrm{~A}_{665}-3.2416 \mathrm{~A}_{632}
$$$$
\text { Chl c }\left(\mu \mathrm{g} \mathrm{g} \mathrm{FW}{ }^{-1}\right)=34.2247 \mathrm{~A}_{632}-1.5492 \mathrm{~A}_{665}
$$

From the same methanolic extract, the absorbance at $470 \mathrm{~nm}$ was used to calculate the total carotenoid concentration using the model proposed by Lichtenthaler (1987), in which absorbance coefficients for $\mathrm{Chl} a(\mathrm{E} \lambda=1.63)$ and $\mathrm{Chl} c(\mathrm{E} \lambda=119.5)$ were based on Lichtenthaler and Buschmann (2001) and Jeffrey (1963), respectively, following the formula modified by Urrea-Victoria and Chow (pers. comm):

\section{Carotenoids $\left(\mu \mathrm{g} \mathrm{FW}^{-1}\right)=\left(1000 \mathrm{~A}_{470}-1.63 \mathrm{Chl} a-\right.$ $119.5 \mathrm{Chl} c) / 221$}

where $\mathrm{A}$ is the absorbance at the respective wavelength.

\section{UV-visible absorption spectra of buffer and methanolic extracts}

From aliquots of $300 \mu \mathrm{L}$ of the buffered and methanolic extracts, UV-absorbing and visible-absorbing compounds were assessed by determining the absorption spectra in a UV-visible microplate spectrophotometer by reading the absorbance in the range of 200 to $750 \mathrm{~nm}$. From the UV- and visible-absorbing spectra of the both extracts, maximal absorption bands were identified and analysed by calculating the area under the curve (AUC) based on the Riemann sum. Data were standardized by the sample biomass in grams (absorbance/biomass).

\section{Seawater UV-visible absorption spectrum}

The absorption spectrum $(200-750 \mathrm{~nm})$ of the seawater, in which samples were cultivated during the experiment, was also recorded using a $300 \mu \mathrm{L}$ aliquot of seawater read in a UV-visible microplate spectrophotometer. Maximal absorption bands were identified and analysed by calculating the AUC of each band based on the Riemann sum.

\section{Data analysis}

Statistical analysis of the data set was performed with the STATISTICA software (version 10.0). Five replicates were used for all studied parameters. Data were checked for normality (Kolmogorov-Smirnov test) and homoscedasticity (Bartlett test) and then submitted to unifactorial, multifactorial or repeated measures analysis of variance (ANOVA), followed by the Newman-Keuls post hoc test to verify the significance of the differences $(\mathrm{p}<0.05)$.

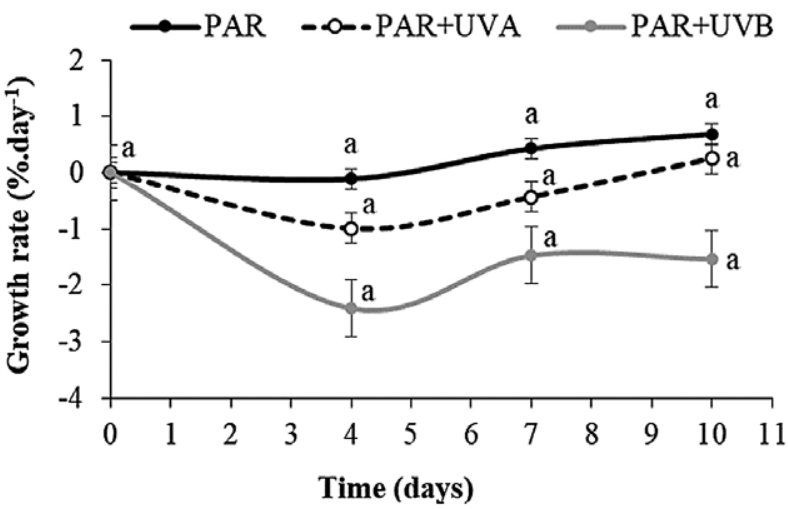

Fig. 2. - Growth rate of Sargassum filipendula over 10 days of exposure to PAR, PAR+UVA, and PAR+UVB radiation treatments $(\mathrm{n}=5 ;$ mean $\pm \mathrm{SD})$. Letters indicate differences according to repeated measures ANOVA.

\section{RESULTS}

\section{Growth rate}

After 10 days of experiment with different radiation treatments (PAR, PAR+UVA, and PAR+UVB), the growth rate of $S$. filipendula analysed by radiation and time (two-way evaluation) showed no differences within the treatments over time (Fig. 2). Despite these results, higher growth rate values were observed for the PAR treatment over time followed by PAR+UVA and then by PAR+UVB (Fig. 1). Also, samples treated with PAR+UVA showed an increase in the growth rate at the tenth day (T10), which was close to the value shown in PAR at the same time. At T10, S. filipendula exposed to UVB treatment showed the most negative growth rate $\left(-1.53 \%\right.$ day $\left.^{-1}\right)$ in comparison with PAR and PAR+UVA $\left(0.68 \%\right.$ day $^{-1}$ and $0.25 \%$ day $^{-1}$, respectively) (Fig. 1).

\section{Proteins and photosynthetic pigments}

Figure 3A shows the content of total soluble proteins of S. filipendula over 10 days of exposure to $\mathrm{PAR}, \mathrm{PAR}+\mathrm{UVA}$, and $\mathrm{PAR}+\mathrm{UVB}$ radiation. With few exceptions, no differences were observed within the days for each radiation treatment, within the radiation for the same time and between the interaction time and radiation. The PAR treatment at T10 showed a noteworthy increase in proteins when compared over time with the same treatment and between the other radiation treatments. Differences were also observed at T7 in PAR+UVA and T10 in PAR+UVB in comparison with PAR. No clear response pattern was observed.

The content of photosynthetic pigments (Chl $a$ and $b$ and carotenoids) in S. filipendula showed little variation when compared over time and after treatment with UV (Fig. 3B-D). No differences were observed in the concentration of $\mathrm{Chl} a$ (Fig. 3B) when compared within times and UV treatments, except for PAR+UVB at T10 $\left(606.46 \pm 2.88 \mu \mathrm{g} \mathrm{g}^{-1}\right)$, in which a significant reduction was evidenced in comparison with the other radiation treatments at the same time $\left(846.90 \pm 3.82 \mu \mathrm{g} \mathrm{g}{ }^{-1}\right.$ for 


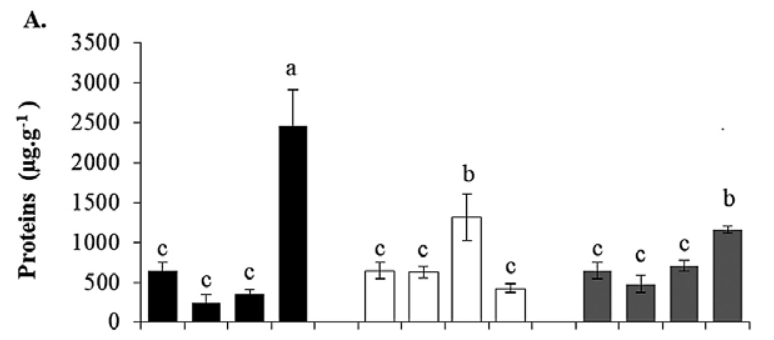

B.

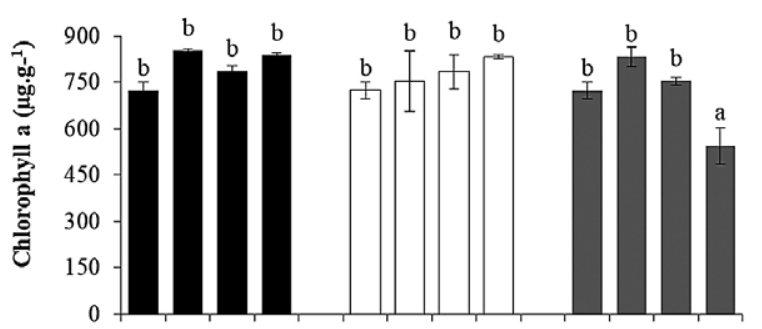

C.

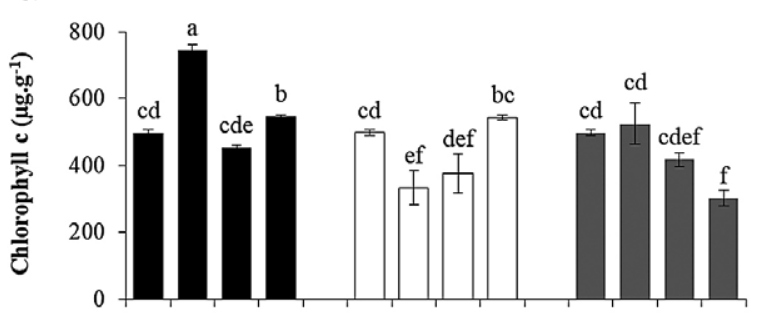

D.

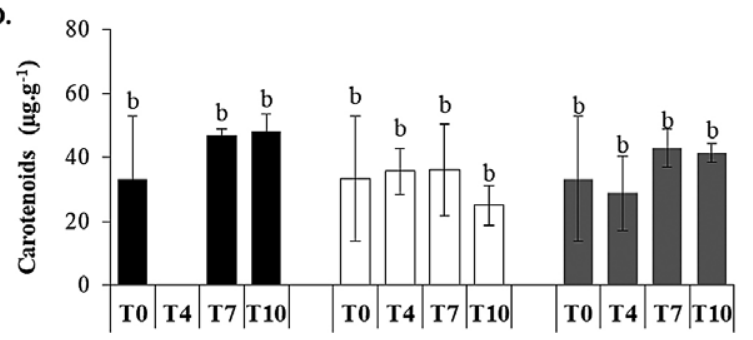

Fig. 3. - A, total soluble proteins; B, chlorophyll $a$; C, chlorophyll $c$; and D, carotenoids of Sargassum filipendula over 10 days of exposure to PAR, PAR+UVA and PAR+UVB radiation treatments $(n=5$; mean \pm SD). T0 represents samples before the start of the experiment and T4, T7 and T10 correspond to the respective exposition time. Letters indicate differences according to bifactorial ANOVA and the Newman-Keuls post hoc test $(\mathrm{p}<0.05)$.

PAR and $833.46 \pm 2.88 \mu \mathrm{g} \mathrm{g}^{-1}$ for PAR+UVA). The content of Chl $c$ showed no clear response trend (Fig. 3C), but it varied significantly over time and among the treatments, showing a reduction at $\mathrm{T} 4$ in PAR+UVA and at T10 in PAR+UVB when compared with the other times and between treatments. Finally, carotenoid concentrations showed no differences over time or between the treatments (Fig. 3D). The samples of $\mathrm{PAR}$ at $\mathrm{T} 4$ were lost, so the mean $\pm \mathrm{SD}$ does not appear in the figure.

\section{UV-visible absorption spectra of buffer and methanolic extracts and seawater}

Considering independently the buffer and methanolic extracts and the seawater samples, a similar pattern of the spectrum profile was observed for all

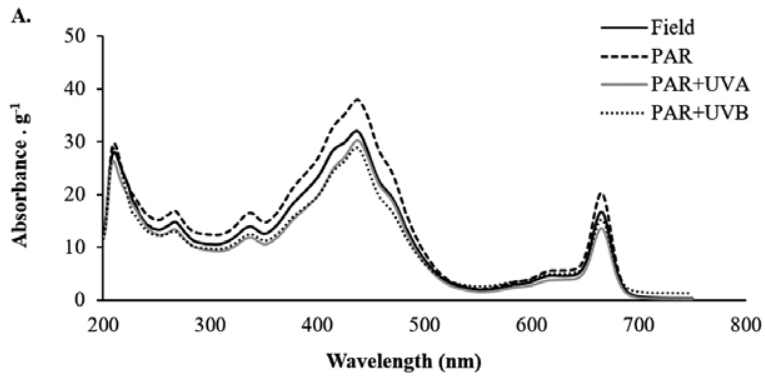

B.

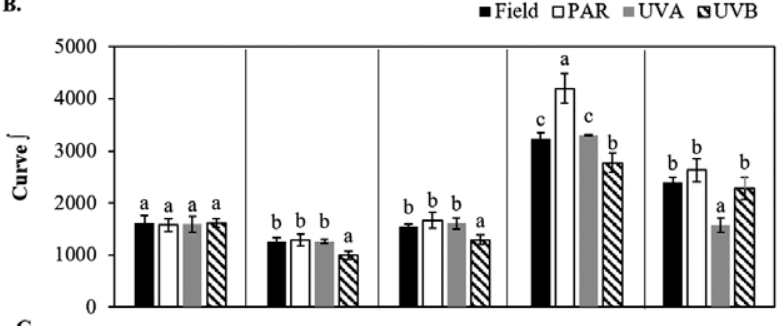

C.

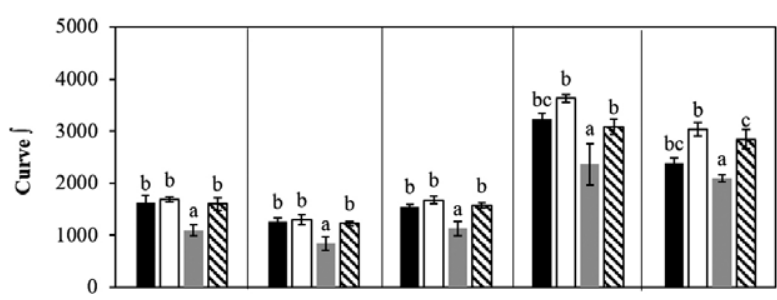

D.

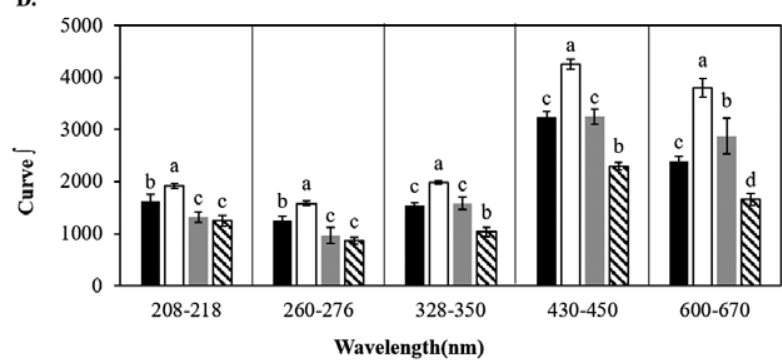

Fig. 4. - Absorption spectrum of buffer extract and area under the curve (AUC) of maximal absorption bands at 220-240 and 260-280 $\mathrm{nm}$. A, general UV spectrum at T4; B, C and D, the AUC $(n=5$; mean \pm SD) at $\mathrm{T} 4, \mathrm{~T} 7$ and $\mathrm{T} 10$ of radiation exposure, respectively, at two specific absorption bands, 220-240 and 260-280 nm. Letters indicate differences according to unifactorial ANOVA and the Newman-Keuls post hoc test $(\mathrm{p}<0.05)$. The analyses were performed for each absorption band separately.

treatments and over time (T4, T,7, and T10), so only one spectrum (T4) for each one is presented. The absorption spectra of buffer and methanolic extracts and seawater are shown in the Figures 4A, 5A and 6A, respectively. Additionally, the AUC for the maximal absorption bands for buffer and methanolic extracts and seawater are represented in Figures 4B-D, 5B-D and 6B-D for T4, T7 and T10.

Figure $3 \mathrm{~A}$ presents the general UV absorption spectrum for buffer extract. Since no maximal absorption bands were observed in the visible region for this extract, the spectrum between 400 and $750 \mathrm{~nm}$ is not shown. Maximal absorption bands were identified between 220-240 and 260-280 nm for T4 (Fig. 4B), T7 (Fig. 4C) and T10 (Fig. 4D). For the times T4 and T7, similar trends were observed, with differences for both wavelength ranges (220-240 and 260-280 $\mathrm{nm}$ ) and a 

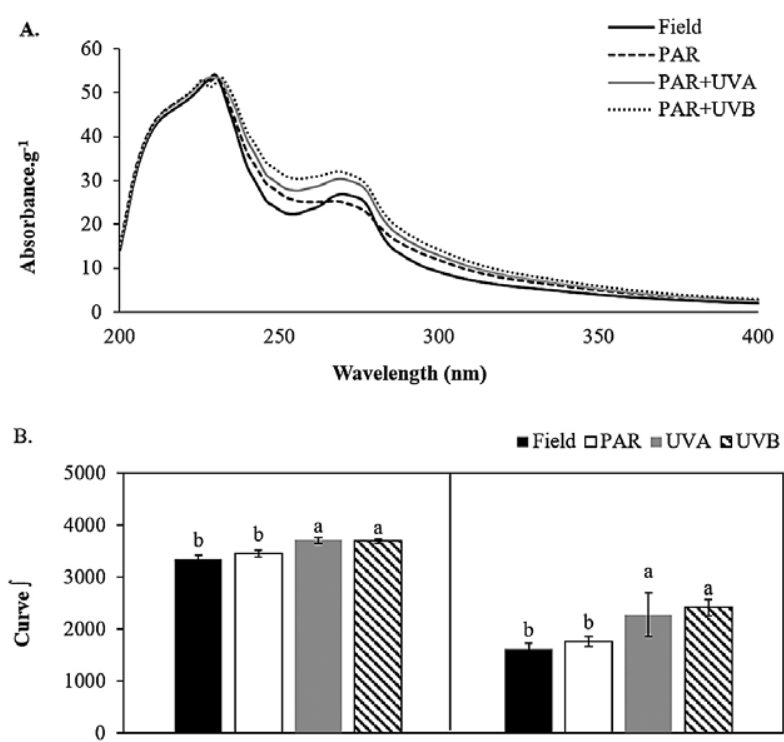

C.
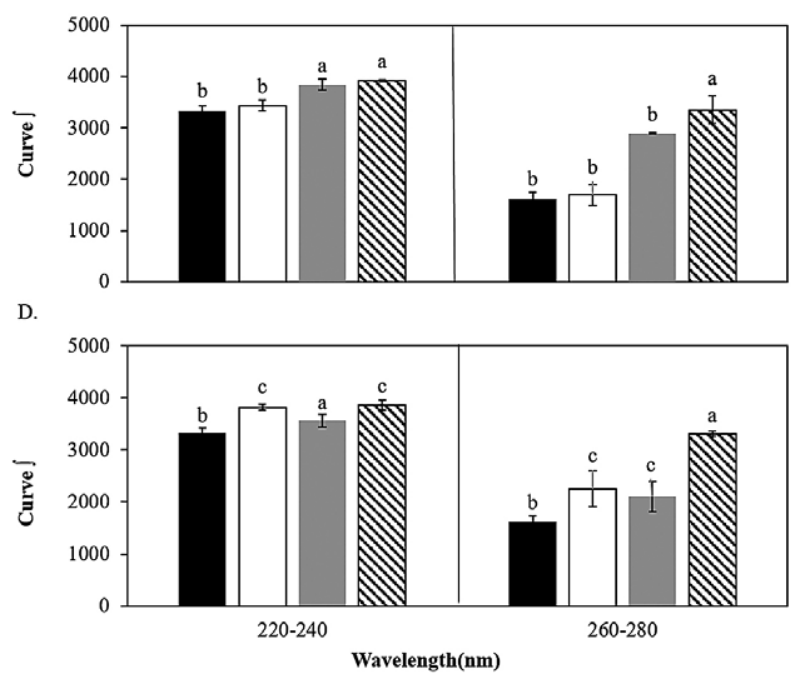

Fig. 5. - Absorption spectrum of methanolic extract and area under the curve (AUC) of maximal UV-visible absorption bands. A, general UV spectrum at T4; B, C and D, the AUC $(n=5 ;$ mean \pm SD) at $\mathrm{T} 4, \mathrm{~T} 7$, and $\mathrm{T} 10$ of radiation exposure, respectively, at three specific UV-absorption bands, 208-218, 260-276 and 328-350 nm, and two specific visible-absorption bands, 430-450 and 600-670 $\mathrm{nm}$. Letters indicate differences according to unifactorial ANOVA and the Newman-Keuls post hoc test $(\mathrm{p}<0.05)$. The analyses were performed for each absorption band separately.

higher AUC for UV radiation treatments than for the PAR treatment. For T10, the amplitude of variances between the PAR and UV radiation treatments was higher for 260-280 nm (Fig. 4D).

For the absorption spectrum of methanolic extract, we identified five maximum bands in the UV-visible spectrum: 208-218, 260-276 and 328-350 $\mathrm{nm}$ for the UV spectrum, and 430-450 and 600-670 nm for the visible spectrum (Fig. 5). More visible-absorbing compounds than UV-absorbing compounds were registered (Fig. 5A). For T4 (Fig. 5B), T7 (Fig. 5C) and T10 (Fig. 5D), similar lower AUC values at UV maximum bands of 260-276, 328-350 and 430-450 nm than visible maximum bands of 430-450 and 600-670 $\mathrm{nm}$ were observed. When comparing the treatments
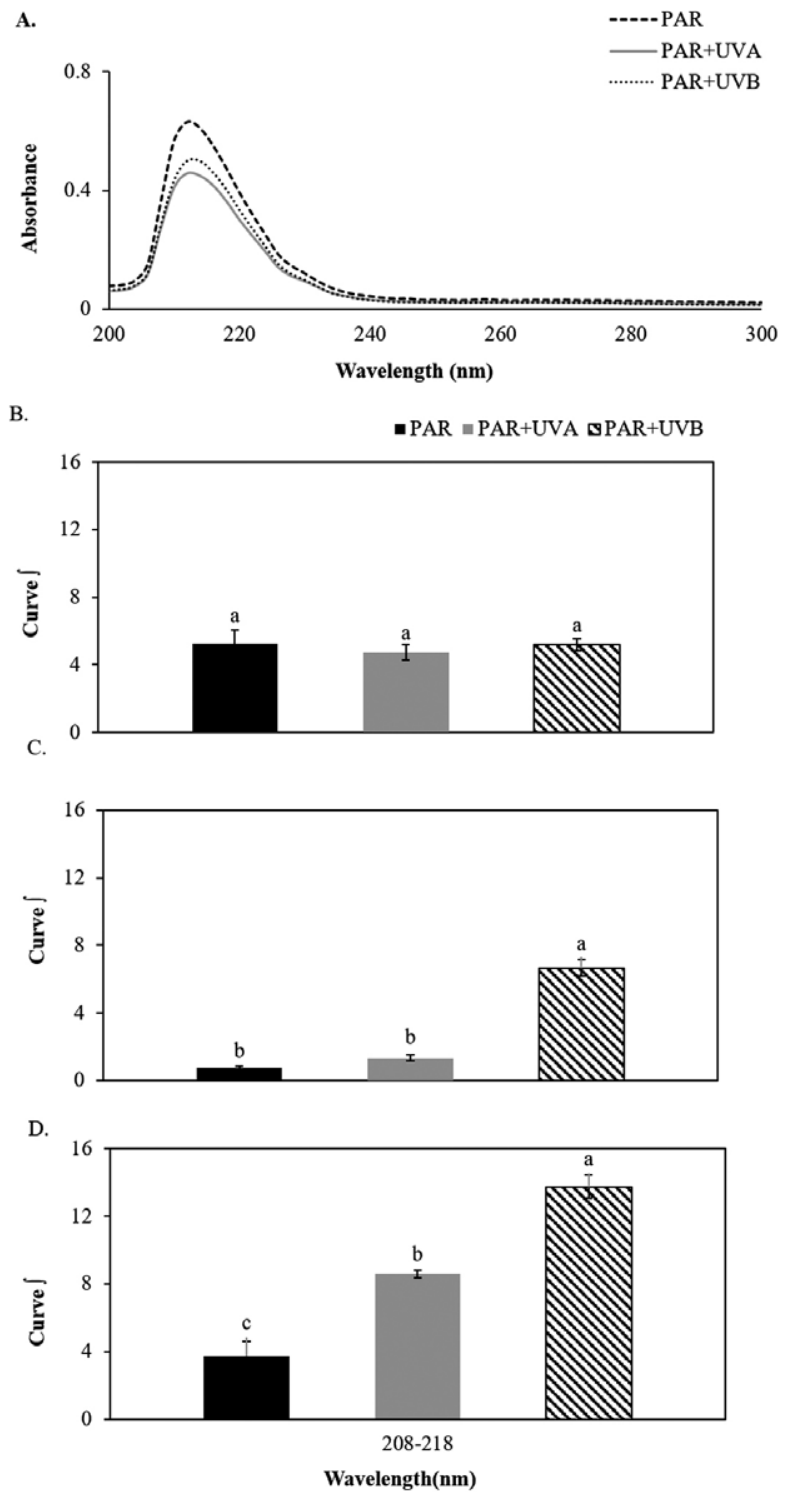

Fig. 6. - Absorption spectrum of seawater and area under the curve (AUC) of maximal UV-visible absorption bands. A, general UV spectrum at T4; B, C and D, the AUC $(n=5 ;$ mean \pm SD) at T4, T7, and T10 of radiation exposure, respectively, at 208-218 nm. Letters indicate differences according to unifactorial ANOVA and the Newman-Keuls post hoc test $(\mathrm{p}<0.05)$.

over time, higher absorbance values were recorded in PAR exposure at both UV and visible regions for T10 (Fig. 5D).

The seawater samples in which the algae were cultivated during the experiment show maximal absorption bands in the UV region, specifically in the range 208$218 \mathrm{~nm}$ (Fig. 6A), and no absorption was observed at visible wavelengths. No differences for AUC among the treatments were observed at T4 (Fig. 6B), whereas at T7 and T10 greater AUC levels were observed for PAR+UVB > PAR+UVA > PAR (Fig. 6C-D, respectively); additionally, the magnitude of UV-absorbing compounds was greater at T10. This last result agrees with the yellowish colour of the seawater after 10 days of UV radiation exposure, compared with a more brownish coloration over the experimental time for the PAR+UVB treatment (Fig. 7). 


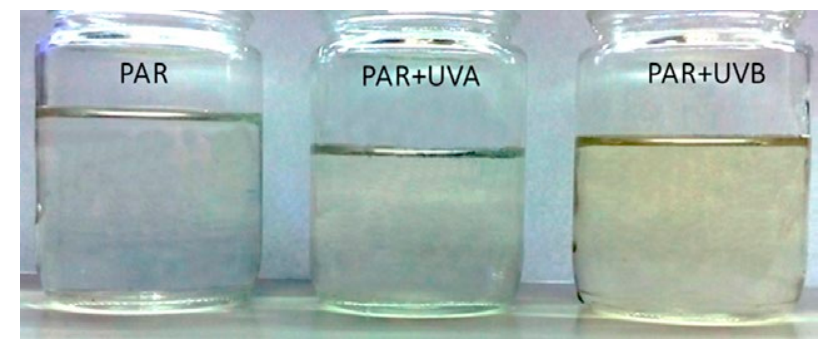

Fig. 7. - Appearance of seawater in which Sargassum filipendula was cultivated after 10 days of experimentation at three different radiation treatments.

\section{DISCUSSION}

Ultraviolet radiation can lead to manifold effects on biological systems, resulting in anatomical, physiological, biochemical and molecular alterations. Therefore, elevated doses of UV radiation trigger acclimation mechanisms in exposed benthic macroalgae, enabling them to tolerate the stressful condition and generating, in turn, a series of responses to maintain control over biological homoeostasis (Viñegla and Figueroa 2009). Furthermore, UV-induced oxidative stress seems to elicit diverse and complex defence mechanisms as a response to avoid cellular damage and assure the hormesis.

The present study shows that the growth rate of $S$. filipendula showed no differences when treated with the specified doses of PAR+UVA and PAR+UVB over 10 days of experiment. Usually, UVA radiation causes indirect DNA damage through the formation of chemical intermediates, such as oxygen and hydroxyl radicals that interact with DNA to form cross-links and breaks in the DNA-protein chain (Dahms et al. 2011). However, moderate doses of UVA such as the one used for this experiment have been shown to stimulate photosynthesis and macroalgal growth, as reported by Döhler et al. (1995) and Xu and Gao (2010). Additionally, as stated by $\mathrm{Xu}$ and Gao (2010), UVA radiation can activate photoprotective mechanisms to counteract the negative effect of UVB radiation, resulting in a decreasing impact of UV radiation on growth rates.

In a previous study using Sargassum cymosum C. Agardh as a biological model to evaluate the combined effects of UV radiation and salinity, Polo et al. (2014a) found that UVA and UVB together in low doses such as the ones used herein stimulated the growth rate, leading to an increase in the amount of mitochondria, which could support the metabolic energy demand required for this process. Indeed, studies with different algal species at low doses of UV radiation show that the UV level modulates diverse physiological responses besides growth through up- or downregulation, such as induction of $\mathrm{Chl} a$, phenolic compounds and antioxidant activity (Polo et al. 2014a), alteration in putrescine/spermidine ratio (Polo et al. 2014b), variation of photosynthetic performance and accessory pigments (Simioni et al. 2014, Schmidt et al. 2015), and ultrastructural organization (Bouzon et al. 2012, Pereira et al. 2017).

At elevated doses of UV radiation $\left(98 \mathrm{~kJ} \mathrm{~m}^{-2}\right.$ and $27 \mathrm{~kJ} \mathrm{~m}^{-2}$ per day for UVA and UVB, respectively), negative effects on algal growth and development are usually related to the damage caused to photosynthetic machinery, photosynthetic pigments, antioxidant enzymes and lipid peroxidation ( $\mathrm{Xu}$ and Gao 2010). Makarov (1999) reported a decrease in growth rate of the brown algae Laminaria saccharina (Linnaeus) J.V. Lamouroux, Alaria esculenta (Linnaeus) Greville, Saccorhiza dermatodea (Bachelot de la Pylaie) J. Agardh, Fucus distichus Linnaeus, $F$. serratus Linnaeus, and $F$. vesiculosus Linnaeus when exposed to UVB radiation. Likewise, Michler et al. (2002) reported a pronounced thallus necrosis and loss of parts of the thalli in the arctic L. solidungula J. Agardh after one week of daily exposure $(18 \mathrm{~h})$ to UV radiation, a process that ultimately led to weight loss. However, it must be taken into account that their study was carried out in the field, with higher doses of UV radiation $\left(324 \mathrm{~kJ} \mathrm{~m}^{-2}\right.$ and $12.96 \mathrm{~kJ} \mathrm{~m}^{-2}$ per day for UVA and UVB, respectively) and a longer exposure time than the experimented with S. filipendula in this study $\left(75.6 \mathrm{~kJ} \mathrm{~m}^{-2}\right.$ and $16.2 \mathrm{~kJ}$ $\mathrm{m}^{-2}$ for UVA and UVB per day, respectively). Tissue deformation observed as partial necrosis of the apical segments has also been reported for red macroalgae such as Gracilaria domingensis (Kützing) Sonder ex Dickie (Schmidt et al. 2010a), Kappaphycus alvarezii (Doty) Doty ex P.C. Silva (Schmidt et al. 2010b) and Gelidium floridanum W.R. Taylor (Schmidt et al. 2012) after UV radiation exposure. In the present study, thallus necrosis was not observed. However, it could be expected that long-term and higher dose exposures to UV radiation may result in tissue deformation and serious damage in $S$. filipendula, and long-term growth measurements and observations on morphological integrity of the algal tissue may represent a more holistic indication of the negative impact of this stress factor (Roleda et al. 2004).

Protein content of $S$. filipendula showed an increase in certain radiation treatments, indicating the possibility of stimulating its accumulation. At control radiation (PAR treatment), an increase in protein level at T10 could represent a response to the nutrient reload caused by the addition of von Stosch enrichment solution to the culture medium after seven days of cultivation. However, this response is unclear. Proteins are known to be strong absorbers of UVB radiation (Karentz 1994), and an increased protein degradation followed by resynthesis in order to replace UVB sensitive proteins could thus be expected during UVB exposure (Cullen and Neale 1994). Repair mechanisms for UVB harm induce damage to membranes and electron transport components, which demand increasing enzymatic activity with higher nitrogen requirements. For example, photosynthetically important proteins such as ribulose-1,5-biphosphate carboxylase/oxygenase (RubisCO) and D1 protein show an increased turnover under UV exposure, leading to a decrease in photosynthetic activity (Aro et al. 1993, Bornman and Teramura 1993, Strid et al. 1994). Moreover, it has been shown that UVB can directly affect the nitrogen uptake system in phytoplankton and leads to decreased uptake rates of ammonium and nitrate (Behrenfeld et al. 1995, Döhler 1997). In addition, algae are more sensitive to environ- 
mental variations when their intracellular nitrogen reserves are exhausted. As reported by some authors, an increase in nitrogen availability, in the form of nitrate and ammonium, will result in higher growth rates in various algae (Chow and Oliveira 2008). In addition, Bischof et al. (2000b) suggest a possible mechanistic linkage between susceptibility to UV radiation and $\mathrm{N}$ metabolism, because the limitation of this element could inhibit D1 protein turnover and the synthesis of RubisCO in the brown macroalga $A$. esculenta. When analysing the UV spectrum

The increase in overall UV-PAR absorption and in absorption at specific ranges are consequences of protein-phenolic interactions. Bonding with phenolics results in the increased absorption of complexes due to the ability of these compounds to absorb UV-PAR radiation. Additionally, the interactions of phenolic compounds with proteins may lead to changes in physico-chemical properties of proteins such as solubility, thermal stability, and digestibility (Labuckas et al. 2008).

Photosynthetic pigments showed little variation during UV exposure within and between treatments. Some authors have reported that UVB radiation is responsible for the loss of photosynthetic pigments (Bischof et al. 2000a, Holzinger and Lütz 2006) and can also reduce the expression of genes involved in photosynthesis (Holzinger and Lütz 2006). When analysing the visible spectrum from methanolic extract, maximal absorption bands were recorded in the region between $430-450$ and $600-670 \mathrm{~nm}$, indicating the presence of Chl $a$ (with maximal absorption bands at 432, 617 and $666 \mathrm{~nm}$ ). However, no differences were observed for $S$. filipendula. Chl $a$ is the main pigment constituent of the reaction centre, in which the D1 protein is closely associated with the occurrence of the electron transport chain of the photosystems. Moreover, the alteration of the size of the harvesting antenna complex and the carotenoid antioxidant composition indicate that photosynthesis is a dynamic process that attempts to safeguard the integrity of the reaction centre and $\mathrm{Chl}$ $a$. Therefore, specifically $\mathrm{Chl} a$ must be tolerant to different stressing impacts, and, as demonstrated in our study, this stability is also observed at moderate UV exposure, showing the ability to acclimate to variations in light intensity and spectral quality (Senger and Bauer 1987, Falkowski and LaRoche 1990).

Additionally, accessory pigments such as Chl $c$ (with maximal absorption bands at 445, 584, and 633 $\mathrm{nm}$ ) and carotenoids were also observed. These pigments serve as an antenna to increase the energy absorption capacity to be directed to the reaction centre. However, under stress conditions, the accessory pigments may be degraded in order to reduce the excess energy being directed to the reaction centre and thus not overburden the Chl $a$ and hence prevent oxidation. These facts could explain the reduction in Chl $c$ observed herein. Similar results were observed by Polo et al. (2014b), in which Chl $c$ was diminished, thus preventing oxidative damage of the photosynthetic apparatus under exposure to UV radiation.

Carotenoids have a recognized antioxidant activity, in which an increase will act as an antioxidant mechanism for protecting the photosynthetic apparatus against oxidative stress. For the present study, total carotenoid content showed no significant variations. According to Teramura (1983), carotenoids are generally less affected than chlorophylls in cropland plants exposed to UVB radiation. Additionally, accumulation of carotenoids specifically in response to UV radiation in both phytoplankton (Goes et al. 1994) and macroalgae (Polo et al. 2014b) suggests that this condition could induce antioxidant defences triggering by these pigments. Within these pigments, fucoxanthin (maximal absorption bands at 428, 448 and $468 \mathrm{~nm}$ ), one of the most abundant carotenoids in brown algae, has attracted considerable interest due to its biological properties, such as antioxidant, anti-inflammatory, anticancer, anti-obese, antidiabetic, antiangiogenic, and antimalarial activities (D'Orazio et al. 2012). The fact that the protection mechanism by pigment degradation and/or increase in carotenoids was apparently not very evident for $S$. filipendula under the UV radiation effect could indicate the participation of other mechanisms in response to UV radiation. As has been recorded for other macroalgae, the establishment of physical barriers such as the increase in the cell wall polysaccharide layer can shield the photosynthetic apparatus against damaging radiation or the induction and synthesis of UV-absorbing compounds, such as phenolic compounds, which are additional mechanisms that might be involved in UV radiation acclimation of radiation protecting processes (Schoenwaelder 2002).

For a large group of organisms, a biological phenomenon referred to as preparation for oxidative stress (POS) has been reported (Hermes-Lima and Storey 1998), in which an antioxidant upregulation linked exclusively to low oxygen stress is established. Several laboratory studies have shown increases in activity of the enzymes catalase, superoxide dismutases, and glutathione peroxidases and reduced levels of glutathione under hypoxia conditions (Moreira et al. 2017). Although POS has not been reported for conditions other than low oxygen, changes in enzymatic and non-enzymatic antioxidant systems have been widely reported for other stress conditions than hypoxia. We therefore suggest the expansion of this term to other situations in which there is activation of the antioxidant systems, as occurs in response to other types of stressors such as UV radiation.

Macroalgae produce a large diversity of UV-absorbing compounds that are known to protect against UV radiation stress (Korbee et al. 2005, Abdala-Diaz et al. 2006). The measurement of the UV-visible absorption spectrum is an easy and valuable tool for comparing the presence and biosynthesis of UV-absorbing compounds and elucidating hypothetic chemical classes with a photoprotective function. For S. filipendula, maximal absorption bands in the UV region were widely observed, suggesting the presence of secondary metabolites such as phenolic compounds, which are largely distributed among brown algae, acting as a defence mechanism (Li et al. 2011) and a potent antioxidant (Al-Azzawie and Alhamdani 2006).

From the maximal UV absorption bands identified in S. filipendula some compounds can be suggested, 
such as tannins with $\lambda$ max near $278 \mathrm{~nm}$, phlorotannins with $\lambda \max$ close to $220-240$ and $260-280 \mathrm{~nm}$, flavonoids such as flavone/flavonols with $\lambda$ max about 210 , $240 / 260$ and $370 \mathrm{~nm}$ (like apigenins) and morin with $\lambda \max$ close to $240-280$ and $350-385 \mathrm{~nm}$, and phenolic acids with $\lambda$ max of $220 \mathrm{~nm}$ and $320 \mathrm{~nm}$ (Chakraborty and Joseph 2016, Abirami and Kowsalya 2017).

Polyphenols are the most prominent phenolic compounds in brown seaweeds, particularly phlorotannins, which are exclusive to this taxon. They are found free or forming complexes with components of the cell walls (Wang et al. 2012), such as polysaccharides, and are essential to the physiological integrity of algae, with important roles involved in chemical defences and protection against oxidative damage in response to changes in nutrient availability and UV radiation ( $\mathrm{Li}$ et al. 2017).

In addition, the $\lambda \max$ at $210 \mathrm{~nm}$ was previously reported by Salgado et al. (2007) in Padina gymnospora (Kützing) Sonder, and the authors attribute this absorption band to a linkage between phenolic compounds and alginates. Other studies in which this linkage has been observed (Schoenwaelder 2002, Berglin et al. 2004, Salgado et al. 2005) reveal that this coupling preserves the UV absorption capability of phenolic compounds over time. Moreover, there is an extensive literature reporting their properties, especially their capacity to act as an antioxidant, with positive effects on human and animal health improving the current interest in disease therapy and chemoprevention (Panche et al. 2016).

The phlorotannins fucophloroethol, phloroethol, eckol, and dieckol have been identified in several species of brown algae, including species of the genus Sargassum (Li et al. 2011). No identification of these compounds was performed in our study, but our results suggest the presence of phlorotannins because they have maximal absorption bands within the ranges observed herein. Additionally, by analysing the ultrastructure of S. cymosum, Polo et al. (2014a) reported the degradation and high migration of phlorotannins contained in physoids through the cell wall as a response caused by UV radiation. This phenomena leads to the liberation of phenolic compounds into the surrounding medium, creating a UV-absorbing microenvironment (UV refuge) (Roleda et al. 2010, Celis-Plá et al. 2014, 2018). This acclimation strategy against UV radiation was also observed in the present study: the seawater that $S$. filipendula was cultivated in during radiation exposure showed a yellowish colour as an indicator of this exudation, with greater intensity in the PAR+UVB treatment.

Our results for S. filipendula show the capacity of the species to synthesize and accumulate UV- and visible-absorbing compounds, probably phlorotannins and carotenoids, respectively, that could provide adaptive advantages for organisms exposed to different ambient stressors such as UV radiation, since brown algae could be more sensitive to UV exposure. This feature is of great importance for macroalgae inhabiting the coasts of Brazil because of the high radiation levels to which they are subjected, especially during low tides and in summer. In addition, the isolation, identification, and comprehension of the biosynthesis action of these compounds will undoubtedly be of great benefit for the development of functional bioproducts with potential application in the medical, pharmaceutical, food and agricultural fields.

In this paper we present the results of a basic research study that contributes to knowledge of the sensitivity and tolerance to UV radiation of $S$. filipendula, a species that is valuable for community structuring in tropical and subtropical marine habitats and is widely distributed on the Brazilian coast in the lower intertidal zone. The integrative data on physiological performance presented herein give insights into the biological implications of this stressor factor for the species. Additionally, the results suggest environmental consequences such as a decrease in primary production due to the possible inhibition of photosynthesis at population level, affecting growth rate and reproduction and leading to the devastation of the trophic base for associated species and the elimination of the ecological niche diversity in this ecosystem. The sensitivity of $S$. filipendula to changes in abiotic factors can therefore be used for environmental monitoring to support decision-making of monitoring and mitigation programmes

\section{ACKNOWLEDGEMENTS}

The authors thank CAPES (Coordination for the Improvement of Higher Education Personnel, Brazil; 2014/2326859) and FAPESP (São Paulo Research Foundation, Brazil; 2016/03095-0) for the PhD fellowships. F. Chow acknowledges a FAPESP research grant (Biota/FAPESP 2013/50731-1) a CNPq research productivity grant (National Council for Scientific and Technological Development, Brazil; 303937/2015-7).

The authors declare that they have no conflict of interest.

\section{REFERENCES}

Abdala-Diaz R.T., Cabello-Pasini A., Pérez-Rodríguez E., et al. 2006. Daily and seasonal variations of optimum quantum yield and phenolic compounds in Cystoseira tamariscifolia (Phaeophyta). Mar. Biol. 148: 459-465. https://doi.org/10.1007/s00227-005-0102-6

Abirami R.G., Kowsalya S. 2017. Quantification and correlation study on derived phenols and antioxidant activity of seaweeds from Gulf of Mannar. J. Herbs, Spices Med. Plants 23: 9-17. https://doi.org/10.1080/10496475.2016.1240132

Al-Azzawie H.F., Alhamdani M.S.S. 2006. Hypoglycemic and antioxidant effect of oleuropein in alloxan-diabetic rabbits. Life Sci. 78: 1371-1377 https://doi.org/10.1016/j.lfs.2005.07.029

Altamirano M., Flores-Moya A., Figueroa F.L. 2003. Effects of UV radiation and temperature on growth of germlings of three species of Fucus (Phaeophyceae). Aquat. Bot. 75: 9-20. https://doi.org/10.1016/S0304-3770(02)00149-3

Amado Filho G.M., Andrade L.R., Karez C.S., et al. 1999. Brown algae species as biomonitors of $\mathrm{Zn}$ and $\mathrm{Cd}$ at Sepetiba Bay, Rio de Janeiro, Brazil. Mar. Environ. Res. 48: 213-224. https://doi.org/10.1016/S0141-1136(99)00042-2

Aro E.M., Virgin I., Andersson B. 1993. Photoinhibition of Photosystem II. Inactivation, protein damage and turnover. BBA - Bioenerg. 1143: 113-134. https://doi.org/10.1016/0005-2728(93)90134-2

Ayres-Ostrock L.M., Plastino E.M. 2014. Effects of short-term exposure to ultraviolet-B radiation on photosynthesis and pigment content of red (wild types), greenish-brown, and green strains of Gracilaria birdiae (Gracilariales, Rhodophyta). J. Appl. Phycol. 26: 867-879. 
https://doi.org/10.1007/s10811-013-0131-3

Bais A.F., McKenzie R.L., Bernhard G., et al. 2015. Ozone depletion and climate change: impacts on UV radiation. Photochem. Photobiol. Sci. 14: 19-52. https://doi.org/10.1039/C4PP90032D

Barufi J., Korbee N., Oliveira M., et al. 2011. Effects of N supply on the accumulation of photosynthetic pigments and photoprotectors in Gracilaria tenuistipitata (Rhodophyta) cultured under UV radiation. J. Appl. Phycol. 23: 457-466. https://doi.org/10.1007/s10811-010-9603-x

Behrenfeld M.J., Lean D.R.S., Lee H. 1995. Ultraviolet-B radiation effects on inorganic nitrogen uptake by natural assemblages of oceanic plankton. J. Phycol. 31: 25-36. https://doi.org/10.1111/j.0022-3646.1995.00025.x

Berglin M., Delage L., Potin P., et al. 2004. Enzymatic cross-linking of a phenolic polymer extracted from the marine alga Fucus serratus. Biomacromolecules 5: 2376-2383. https://doi.org/10.1021/bm0496864

Bischof K., Hanelt D., Tüg H., et al. 1998. Acclimation of brown algal photosynthesis to ultraviolet radiation in Arctic coastal waters (Spitsbergen, Norway). Polar Biol. 20: 388-395. https://doi.org/10.1007/s003000050319

Bischof K., Hanelt D., Wiencke C. 2000a. Effects of ultraviolet radiation on photosynthesis and related enzyme reactions of marine macroalgae. Planta 211: 555-562. https://doi.org/10.1007/s004250000313

Bischof K., Kräbs G., Hanelt D., et al. 2000b. Photosynthetic characteristics and mycosporine-like amino acids under UV radiation: A competitive advantage of Mastocarpus stellatus over Chondrus crispus at the Helgoland shoreline? Helgol. Mar. Res. 54: $47-52$ https://doi.org/10.1007/s101520050035

Björn L.O. 2007. Stratospheric ozone, ultraviolet radiation, and cryptogams. Biol. Conserv. 135: 326-333. https://doi.org/10.1016/j.biocon.2006.10.006

Bornman J.F., Teramura A.H. 1993. Effects of enhanced UV-B radiation on terrestrial plants. In: Young A.R., Bjorn L.O., et al. (eds) Environmental UV Photobiology. Plenum Press, New York, pp, 427-471. https://doi.org/10.1007/978-1-4899-2406-3_14

Bouzon Z.L., Chow F., Zitta C.S., et al. 2012. Effects of natural radiation, photosynthetically active radiation and artificial ultraviolet radiation-b on the chloroplast organization and metabolism of Porphyra acanthophora var. brasiliensis (Rhodophyta, Bangiales). Microsc. Microanal. 18: 1467-1479. https://doi.org/10.1017/S1431927612013359

Bradford M.M. 1976. A rapid and sensitive method for the quantitation of microgram quantities of protein utilizing the principle of protein-dye binding. Anal. Biochem. 72: 248-254. https://doi.org/10.1016/0003-2697(76)90527-3

Buma A.G.J., Walter Helbling E., Karin De Boer M., et al. 2001. Patterns of DNA damage and photoinhibition in temperate South-Atlantic picophytoplankton exposed to solar ultraviolet radiation. J. Photochem. Photobiol. B Biol. 62: 9-18. https://doi.org/10.1016/S1011-1344(01)00156-7

Celis-Plá P.S.M., Korbee N., Gómez-Garreta A., et al. 2014. Patrones estacionales de fotoaclimatación en el alga intermareal, Cystoseira tamariscifolia (Ochrophyta). Sci. Mar. 78: 377-388. https://doi.org/10.3989/scimar.04053.05A

Celis-Plá P.S.M., Brown M.T., Santillán-Sarmiento A., et al. 2018. Ecophysiological and metabolic responses to interactive exposure to nutrients and copper excess in the brown macroalga Cystoseira tamariscifolia. Mar. Pollut. Bull. 128: 214-222. https://doi.org/10.1016/j.marpolbul.2018.01.005

Chakraborty K., Joseph D. 2016. Antioxidant potential and phenolic compounds of brown seaweeds Turbinaria conoides and Turbinaria ornata (Class: Phaeophyceae). J. Aquat. Food. Prod. Technol. 25: 1249-1265. https://doi.org/10.1080/10498850.2015.1054540

Chow F., De Oliveira M.C. 2008. Rapid and slow modulation of nitrate reductase activity in the red macroalga Gracilaria chilensis (Gracilariales, Rhodophyta): Influence of different nitrogen sources. J. Appl. Phycol. 20: 775-782. https://doi.org/10.1007/s10811-008-9310-z

Cruces E., Huovinen P., Gómez I. 2013. Interactive effects of UV radiation and enhanced temperature on photosynthesis, phlorotannin induction and antioxidant activities of two sub-Antarctic brown algae. Mar. Biol. 160: 1-13. https://doi.org/10.1007/s00227-012-2049-8

Cullen J., Neale P. 1994. Ultraviolet radiation, ozone depletation, and marine photosynthesis. Photosynth. Res. 39: 303-320. https://doi.org/10.1007/BF00014589

D’Orazio N., Gemello E., Gammone M.A., et al. 2012. Fucoxantin: A treasure from the sea. Mar. Drugs 10: 604-616. https://doi.org/10.3390/md10030604

Dahms H.U., Dobretsov S., Lee J.S. 2011. Effects of UV radiation on marine ectotherms in polar regions. Comp. Biochem. Physiol. - C Toxicol. Pharmacol. 153: 363-371. https://doi.org/10.1016/j.cbpc.2011.01.004

Diffey B.L. 2002. Sources and measurement of ultraviolet radiation. Methods 28: 4-13. https://doi.org/10.1016/S1046-2023(02)00204-9

Döhler G. 1997. Impact of UV radiation of different wavebands on pigments and assimilation of $15 \mathrm{~N}$-ammonium and $15 \mathrm{~N}$-nitrate by natural phytoplankton and ice algae in Antarctica. J. Plant. Physiol. 151: 550-555. https://doi.org/10.1016/S0176-1617(97)80229-5

Döhler G., Hagmeier E., David C. 1995. Effects of solar and artificial UV irradiation on pigments and assimilation of $15 \mathrm{~N}$ ammonium and $15 \mathrm{~N}$ nitrate by macroalgae. J. Photochem. Photobiol. B Biol. 30: 179-187. https://doi.org/10.1016/1011-1344(95)07189-9

Edwards P. 1970. Illustre ated guide of seaweeds and sea grasses in vicinity of Porto Arkansas, Texas. Contrib. Mar. Sci. 15: 1-228.

Falkowski P., LaRoche J. 1990. Acclimation to spectral irradiance in algae. J. Phycol. 27: 8-14. https://doi.org/10.1111/j.0022-3646.1991.00008.x

Figueroa F.L., Domínguez-González B., Korbee N. 2014. Vulnerability and acclimation to increased UVB radiation in three intertidal macroalgae of different morpho-functional groups. Mar. Environ. Res. 97: 30-38. https://doi.org/10.1016/j.marenvres.2014.01.009

Gao K., Xu J. 2008. Effects of solar UV radiation on diurnal photosynthetic performance and growth of Gracilaria lemaneiformis (Rhodophyta). Eur. J. Phycol. 43: 297-307. https://doi.org/10.1080/09670260801986837

Goes J.I., Handa N., Taguchi S., et al. 1994. Effect of UV-B radiation on the fatty-acid composition of the marine-phytoplankton Tetraselmis $\mathrm{sp}$.: relationship to cellular pigments. Mar. Ecol. Prog. Ser. 114: 259-274. https://doi.org/10.3354/meps114259

Gorostiaga J.M., Díez I. 1996. Changes in the sublittoral benthic marine macroalgae in the polluted area of Abra de Bilbao and proximal coast (Northern Spain). Mar. Ecol. Prog. Ser. 130: 157-167. https://doi.org/10.3354/meps130157

Häder D.-P., Kumar H.D., Smith R.C., et al. 2007. Effects of solar UV radiation on aquatic ecosystems and interactions with climate change. Photochem. Photobiol. Sci. 6: 267-285. https://doi.org/10.1039/B700020K

Heo S.J., Jeon Y.J. 2009. Protective effect of fucoxanthin isolated from Sargassum siliquastrum on UV-B induced cell damage. J. Photochem. Photobiol. B Biol. 95: 101-107. https://doi.org/10.1016/j.jphotobiol.2008.11.011

Hermes-Lima M., Storey K. 1998. Role of antioxidant defenses in the tolerance of severe dehydration by anurans. The case of the leopard frog Rana pipiens. Mol. Cell. Biochem. 189: 79-89. https://doi.org/10.1023/A: 1006868208476

Holzinger A., Lütz C. 2006. Algae and UV irradiation: Effects on ultrastructure and related metabolic functions. Micron 37: 190-207. https://doi.org/10.1016/j.micron.2005.10.015

Holzinger A., di Piazza L., Lütz C., et al. 2011. Sporogenic and vegetative tissues of Saccharina latissima (Laminariales, Phaeophyceae) exhibit distinctive sensitivity to experimentally enhanced ultraviolet radiation: Photosynthetically active radiation ratio. Phycol. Res. 59: 221-235. https://doi.org/10.1111/j.1440-1835.2011.00620.x

Jeffrey S.W. 1963. Purification and Properties of Chlorophyll c from Sargassum flavicans. Biochem. J. 86: 313-318. https://doi.org/10.1042/bj0860313

Karentz D. 1994. Ultraviolet tolerance mechanisms in Antarctic marine organisms. Antarct. Res. Ser. 62: 93-110.

Khotimchenko S.V., Yakovleva I.M. 2005. Lipid composition of the red alga Tichocarpus crinitus exposed to different levels of photon irradiance. Phytochemistry 66: 73-79. https://doi.org/10.1016/j.phytochem.2004.10.024

Korbee N., Huovinen P., Figueroa F.L., et al. 2005. Availability of ammonium influences photosynthesis and the accumulation of mycosporine-like amino acids in two Porphyra species (Bangi- 
ales, Rhodophyta). Mar. Biol. 146: 645-654. https://doioro/10.1007/s00227-004-1484-6

Kumar A., Tyagi M.B., Jha P.N. 2004. Evidences showing ultraviolet-B radiation-induced damage of DNA in cyanobacteria and its detection by PCR assay. Biochem. Biophys. Res. Commun. 318: $1025-1030$ https://doi.org/10.1016/j.bbrc.2004.04.129

Labuckas D.O., Maestri D.M., Perelló M., et al. 2008. Phenolics from walnut (Juglans regia L.) kernels: Antioxidant activity and interactions with proteins. Food. Chem. 107: 607-612. https://doi.org/10.1016/j.foodchem.2007.08.051

Lee T.M., Shiu C.T. 2009. Implications of mycosporine-like amino acid and antioxidant defenses in UV-B radiation tolerance for the algae species Ptercladiella capillacea and Gelidium amansii. Mar. Environ. Res. 67: 8-16. https://doi.org/10.1016/j.marenvres.2008.09.006

Li Y.X., Wijesekara I., Li Y., et al. 2011. Phlorotannins as bioactive agents from brown algae. Process. Biochem. 46: 2219-2224. https://doi.org/10.1016/j.procbio.2011.09.015

Li Y., Fu X., Duan D. et al. 2017. Extraction and identification of phlorotannins from the brown alga, Sargassum fusiforme (Harvey) Setchell. Mar. Drugs. 15: 1-15. https://doi.org/10.3390/md15020049

Liang Y., Beardall J., Heraud P. 2006. Effects of nitrogen source and UV radiation on the growth, chlorophyll fluorescence and fatty acid composition of Phaeodactylum tricornutum and Chaetoceros muelleri (Bacillariophyceae). J. Photochem. Photobiol. B Biol. 82: 161-172. https://doi.org/10.1016/j.jphotobiol.2005.11.002

Lichtenthaler H.K. 1987. Chlorophylls and carotenoids: Pigments of photosynthetic biomembranes. In: Packer L., Douce R. (eds), Plant Cell Membranes. Methods Enzymol. 148: 350-382. https://doi.org/10.1016/0076-6879(87)48036-1

Lichtenthaler H.K., Buschmann C. 2001. Chlorophylls and carotenoids: measurement and characterization by UV-VIS spectroscopy. Curr. Protoc. Food. Anal. Chem. 1: F4.3.1-F4.3.8. https://doi.org/10.1002/0471142913.faf0403s01

Lippert H., Iken K., Rachor E., et al. 2001. Macrofauna associated with macroalgae in the Kongsfjord (Spitsbergen). Polar Biol. 24: $512-522$ https://doi.org/10.1007/s003000100250

Madronich S., McKenzie R.L., Björn L.O., et al. 1998. Changes in biologically active ultraviolet radiation reaching the Earth's surface. J. Photochem. Photobiol. B Biol. 46: 5-19. https://doi.org/10.1016/S1011-1344(98)00182-1

Makarov M. 1999. Influence of ultraviolet radiation on the growth of the dominant macroalgae of the Barents Sea. Chemosph Glob. Chang. Sci. 1: 461-467. https://doi.org/10.1016/S1465-9972(99)00034-3

Michler T., Aguilera J., Hanelt D., et al. 2002. Long-term effects of ultraviolet radiation on growth and photosynthetic performance of polar and cold-temperate macroalgae. Mar. Biol. 140: 1117-1127. https://doi.org/10.1007/s00227-002-0791-z

Moreira D.C., Oliveira M.F., Liz-Guimarães L., et al. 2017. Current trends and research challenges regarding "preparation for oxidative stress". Front. Physiol. 8: 1-8. https://doi.org/10.3389/fphys.2017.00702

Navarro N.P., Figueroa F.L., Korbee N., et al. 2016. Differential responses of tetrasporophytes and gametophytes of Mazzaella laminarioides (Gigartinales, Rhodophyta) under solar UV radiation. J. Phycol. 52: 451-462. https://doi.org/10.1111/jpy.12407

Panche A.N., Diwan A.D., Chandra S.R. 2016. Flavonoids: An overview. J. Nutr. Sci. 5: 1-15. https://doi.org/10.1017/jns.2016.41

Paula E.J., Eston V.R. 1987. Are there other Sargassum species potentially as invasive as S. muticum? Bot. Mar. 30: 405-410. https://doi.org/10.1515/botm.1987.30.5.405

Penniman C., Mathieson C., Penniman C.E. 1986. Reproductive phenology and growth of Gracilaria tikvahiae McLachlan (Gigartinales, Rhodophyta) in the Great Bay Estuary, New Hampshire. Bot. Mar. 29: 147-154 https://doi.org/10.1515/botm.1986.29.2.147

Pereira D.T., Simioni C., Ouriques L.C., et al. 2017. Comparative study of the effects of salinity and UV radiation on metabolism and morphology of the red macroalga Acanthophora spicifera (Rhodophyta, Ceramiales). Photosynthetica 56: 799-810. https://doi-org/10.1007/s11099-017-0731-2

Polo L.K., Felix M., Kreusch M. et al. 2014a. Photoacclimation responses of the brown macroalga Sargassum cymosum to the combined influence of UV radiation and salinity: Cytochemical and ultrastructural organization and photosynthetic performance. Photochem. Photobiol. 90: 560-573. https://doi.org/10.1111/php.12224

Polo L.K., Felix M., Kreusch M., et al. 2014b. Metabolic profile of the brown macroalga Sargassum cymosum (Phaeophyceae, Fucales) under laboratory UV radiation and salinity conditions. J. Appl. Phycol. 27: 887-899. https://doi.org/10.1007/s10811-014-0381-8

Ritchie R.J. 2008. Universal chlorophyll equations for estimating chlorophylls $a, b, c$, and d and total chlorophylls in natural assemblages of photosynthetic organisms using acetone, methanol, or ethanol solvents. Photosynthetica 46: 115-126. https://doi.org/10.1007/s11099-008-0019-7

Roleda M.Y., Hanelt D., Kräbs G., et al. 2004. Morphology, growth, photosynthesis and pigments in Laminaria ochroleuca (Laminariales, Phaeophyta) under ultraviolet radiation. Phycologia 43: 603-613. https://doi.org/10.2216/i0031-8884-43-5-603.1

Roleda M.Y., Lüder U.H., Wiencke C. 2010. UV-susceptibility of zoospores of the brown macroalga Laminaria digitata from Spitsbergen. Polar Biol. 33: 577-588. https://doi.org/10.1007/s00300-009-0733-z

Ruhland C.T., Fogal M.J., Buyarski C.R., et al. 2007. Solar ultraviolet-B radiation increases phenolic content and ferric reducing antioxidant power in Avena sativa. Molecules 12: 1220-1232. https://doi.org/10.3390/12061220

Salgado LT., Andrade L.R., Amado G.M. 2005. Localization of specific monosaccharides in cells of the brown alga Padina gymnospora and the relation to heavy-metal accumulation. Protoplasma 225: 123-128. https://doi.org/10.1007/s00709-004-0066-2

Salgado L.T., Tomazetto R., Cinelli L.P., et al. 2007. The influence of brown algae alginates on phenolic compounds capability of ultraviolet radiation absorption in vitro. Brazilian J. Oceanogr. 55: $145-154$ https://doi.org/10.1590/S1679-87592007000200007

Sampath-Wiley P., Neefus C.D., Jahnke L.S. 2008. Seasonal effects of sun exposure and emersion on intertidal seaweed physiology: fluctuations in antioxidant contents, photosynthetic pigments and photosynthetic efficiency in the red alga Porphyra umbilicalis. J. Exp. Mar. Bio. Ecol. 361: 83-91 https://doi.org/10.1016/j.jembe.2008.05.001

Schmidt É.C., dos Santos R., Horta P.A., et al. 2010a. Effects of UVB radiation on the agarophyte Gracilaria domingensis (Rhodophyta, Gracilariales): Changes in cell organization, growth and photosynthetic performance. Micron 41: 919-930. https://doi.org/10.1016/j.micron.2010.07.010

Schmidt É.C., Maraschin M., Bouzon Z.L. 2010b. Effects of UVB radiation on the carragenophyte Kappaphycus alvarezii (Rhodophyta, Gigartinales): Changes in ultrastructure, growth, and photosynthetic pigments. Hydrobiologia 649: 171-182. https://doi.org/10.1007/s10750-010-0243-6

Schmidt É.C., dos Santos R.W., de Faveri C., et al. 2012. Response of the agarophyte Gelidium floridanum after in vitro exposure to ultraviolet radiation B: Changes in ultrastructure, pigments, and antioxidant systems. J. Appl. Phycol. 24: 1341-1352. https://doi.org/10.1007/s10811-012-9786-4

Schmidt E.C., Kreusch M., Felix M., et al. 2015. Effects of ultraviolet radiation (UVA+UVB) and copper on the morphology, ultrastructural organization and physiological responses of the red alga Pterocladiella capillacea. Photochem. Photobiol. 91: 359-370. https://doi.org/10.1111/php.12396

Schoenwaelder M.E. 2002. The occurrence and cellular significance of physodes in brown algae. Phycologia 41: 125-139. https://doi.org/10.2216/i0031-8884-41-2-125.1

Senger H., Bauer B. 1987. The influence of light quality on adaptation and function of the photosynthetic apparatus. Photochem. Photobiol. 45: 939-946. https://doi.org/10.1111/j.1751-1097.1987.tb07905.x

Simioni C., Schmidt É.C., Felix M., et al. 2014. Effects of ultraviolet radiation (UVA+UVB) on young gametophytes of Gelidium floridanum: Growth rate, photosynthetic pigments, carotenoids, photosynthetic performance, and ultrastructure. Photochem. Photobiol. 90: 1050-1060. https://doi.org/10.1111/php.12296

Strid A., Chow W.S., Anderson J.M. 1994. UV-B damage and protection at the molecular level in plants. Photosynth. Res. 39: 
475-489.

https://doi.org/10.1007/BF00014600

Széchy M.T.M., Veloso V.G., De Paula É.J. 2001. Brachyura (Decapoda, Crustacea) of phytobenthic communities of the sublittoral region of rocky shores of Rio de Janeiro and São Paulo, Brazil. Trop. Ecol. 42: 231-242.

Teramura A.H. 1983. Effects of ultraviolet B radiation on the growth and yield of crop plants. Physiol. Plant. 58: 415-427. https://doi.org/10.1111/j.1399-3054.1983.tb04203.x

Ursi S., Plastino E.M. 2001. Crescimento in vitro de linhagens de coloração vermelha e verde clara de Gracilaria birdiae (Gracilariales, Rhodophyta) em dois meios de cultura: análise de diferentes estádios reprodutivos. Rev. bras. Bot. 24: 587-594. https://doi.org/10.1590/S0100-84042001000500014

Villafañe V.E., Sundback K., Figueroa F.L., et al. 2003. Environment, Photosynthesis in the aquatic UVR, as affected by UVR. In: Helbling E., Zagarese H. (eds), UV Effects in Aquatic
Organisms and Ecosystems. Comprehensive Series in Photochemical and Photobiological Sciences, pp 359-383.

Viñegla B., Figueroa F. 2009. Effect of solar and artificial UV radiation on photosynthetic performance and carbonic anhydrase activity in intertidal macroalgae from southern Spain. Ciencias Mar. 35: 59-74. https://doi.org/10.7773/cm.v35i1.1512

Wang W., Wang S.X., Guan H.S. 2012. The antiviral activities and mechanisms of marine polysaccharides: An overview. Mar. Drugs 10: 2795-2816. https://doi.org/10.3390/md10122795

Xu J., Gao K. 2010. UV-A enhanced growth and UV-B induced positive effects in the recovery of photochemical yield in Gracilaria lemaneiformis (Rhodophyta). J. Photochem Photobiol. B Biol. 100: 117-122.

https://doi.org/10.1016/j.jphotobiol.2010.05.010 